\title{
Sciendo
}

Journal of Intercultural

Management

Vol. 13 | No. 2 | June 2021

pp. 29-58

DOI 10.2478/joim-2021-0060

\section{Michał Szostak}

University of Social Sciences,

Warsaw, Poland

mszostak@san.edu.pl

ORCID ID: 0000-0002-7774-2964

\section{Does Polish Post-Communist \\ Cultural Burden Influence \\ the Perception of Creative Identities?}

Received: 06-05-2021; Accepted: 06-06-2021

\section{ABSTRACT}

Objective: Post-communist countries, affected by decades of one of the most repressive political systems, are perceived as a particular area of gaps in social capital. These gaps influence the whole spectrum of behaviors of individuals, groups, and society. Countries that changed their political system start a journey of external (economic, social) and internal (personal, interpersonal, group) changes. The post-communist burden determines human behavior, so leaders and managers should pay attention to these consequences. The research deals with the differences in perception of creative identities (a creator, artist, 
manager, entrepreneur, and leader) by Polish society compared to other countries without communist history.

Methodology: Quantitative research $(n=160)$ in the form of a survey among people from Poland and other countries. Verification of hypotheses by chisquare test of independence used (SPSS, MS Excel). Next, a qualitative analysis of discrepancies was undertaken (NVivo).

Findings: There are no statistical differences in the perception of creative identities of a creator, artist, manager, entrepreneur, and leader between citizens of Poland and citizens of other countries. The additional qualitative analysis exposed that differences in perception of the creative identities between investigated societies might have necessary consequences while managing or leading groups (and organizations) dominated by creative individuals. These differences are shown in detail, and links between our research results and the literature are built.

Value Added: It looks like a post-communist burden in current Poland has a minimal impact on the perception of creative individuals. Thus, it can be said that communism disappears from the social capital during one generation (ca. 30 years).

Recommendations: Further research exploring the perception of creative identities by different analogical groups of compared societies would be valuable.

Key words: Social capital, creator's identity, artist's identity, manager's identity, entrepreneur's identity, leader's identity, creativity

JEL codes: D91, J19, L26, M54, Z11

\section{Introduction}

Social identity theory (social psychology) interest deals with the relations between personal and social identities. It specifies the conditions when an individual thinks of himself as an autonomous individual or group member. From this perspective, the consequences of personal and social identities for individual perceptions and group behavior should be respected (Wolf, 2019). Using 
this perspective, each country, being a specific group of people creating and using the same culture, influences the identities of its citizens. Parallelly, personal identity, being one of the basic foundations establishing an individual, is not an accessible area for researchers, mainly if they focus on the managerial side of the problem and its organizational consequences. Due to the strictly psychological characteristics of the research area (identity), management scientists, being weaker armed in tools than psychologists, attempt to determine canons that can help include different identities in management practice. This philosophy was the initial point for this research.

Although external factors, like the social and intellectual background, primary material wealth, or just luck, affect each person's fortune, it is the identity being the steering power behind an individual's personal and professional life cycle. Previous research in the area of creator's, artist's, manager's, entrepreneur's, and leader's identities discovered that even the persons who own gifts, personal characteristics, and well recognized professional positions in the above fields have problems to define of who a creative person is, who an artist is, who a manager is, who an entrepreneur is, or who a leader is. These indistinct "definitions" of the particular identities directed the researchers to isolate the complex identities like artists-managers (Szostak \& Sułkowski, 2020a; 2021b; 2020b) or artists-entrepreneurs (Szostak \& Sułkowski, 2021a). Even the individuals with highly developed abilities allowing to describe their characteristics have many problems with the distinction between the creative and noncreative artist/manager/entrepreneur/leader.

The above considerations guided to compare the perception of a creator, artist, manager, entrepreneur, and leader by Polish and non-Polish citizens. Following this purpose, the research hypotheses were established: $\mathrm{H} 1)$ Polish citizens perceive the creative identities of a creator, artist, manager, entrepreneur, and leader differently than citizens of the rest of the world. H2) The differences in the perception of creative identities of a creator, artist, manager, entrepreneur, and leader by Polish and non-Polish 
citizens are not the same and vary in the case of each of the above identities.

\section{Materials \& Methods}

Initially, secondary research in the form of reviewing literature was undertaken (NVivo Pro). The literature review approach was based on a qualitative selection of materials from EBSCO, Google Scholar, JSTOR, Mendeley, Scopus, and Web of Science. The methodological approach was based on an interdisciplinary and multiparadigm tactic referring to arts and aesthetics, creativity, management, entrepreneurship, and leadership.

Secondly, quantitative research in the form of a questionnaire was conducted. The survey was established on the approach of Stefan Nowak (2007), containing the dimensions of the studied phenomenon and selecting indicators allowing describing the studied phenomenon. The initial methodological idea assumed constructing separate sets of indicators for each of the analyzed dimensions. Sets of indicators for individual dimensions began to be developed based on the literature on the subject in the field of: artistry (Bayrakci et al., 2009; McHugh, 2015; Szostak, 2020; Walter, 2015; Wilson \& Brown, 2012; Woodward \& Funk, 2010), creativity (Dufour, Maoret, \& Montani, 2020; Gangi, 2018; Lehmann \& Gaskins, 2019; Leso et al., 2017; Szostak \& Sułkowski, 2020a; Taleghani, 2012; Zhou, Shin, \& Cannella, 2008), managerial issues (Baker et al., 2012; Bulei, Mihalcioiu, \& Tucmeanu, 2014; Elstad \& Jansson, 2020; Hallier, 2004; Hatch, Kostera, \& Koźmiński, 2006; Hracs, 2015; Lähdesmäki, 2012; López-Fernández, Romero-Fernández, \& Aust, 2018; Lutas, Nistor, Radu, \& Beleiu, 2020), leadership (Adler, 2006; Alvesson \& Blom, 2015; Carroll \& Levy, 2008; Jankurová, Ljudvigová, \& Gubová, 2017; Lord \& Brown, 2001; Nikolski, 2015; Postuła \& Majczyk, 2018; Raso, Fitzpatrick, \& Masick, 2020; Stuke, 2013; Woodward \& Funk, 2010), and entrepreneurship (Bureau \& Zander, 2014; 
Clarke \& Holt, 2019; Damásio \& Bicacro, 2017; Lewis, Ho, Harris, \& Morrison, 2016; Postuła \& Majczyk, 2018; Toscher, 2019; 2020). However, the analysis of individual groups of indicators showed that, in principle, each of the indicators selected for individual dimensions might be used to describe each of the examined dimensions. Following this assumption, a single list of 50 of the same indicators was compiled and applied to all five examined dimensions. Thanks to the above, the obtained results may be compared to the same indicators for other dimensions.

The survey was ultimately divided into four segments. In the first section, a list of questions (each question related to one indicator) was divided into thematic units referring to each analyzed dimension: artistry, creativity, entrepreneurship, leadership, and managerial issues. All questions were closed, and a five-point Likert scale was formed to answer: definitely not, rather not, hard to say, rather yes, and definitely yes. In the second part of the investigation, questions were raised describing relationships of the analyzed dimensions to the other dimensions. In the third segment, the respondents explained their identity concerning each of the dimensions. Finally, the fourth part included questions classifying the respondents, i.e., gender, age, education, their assessment of their own identity (as a creator, artist, manager, entrepreneur, leader).

The nonparametric chi-square test of independence dedicated to small samples that do not have a normal distribution was used to verify the hypotheses. The pairs of the observed values were compared with pairs of the expected values for each hypothesis. The $p$-value of the tests was $<0.001$. Data analysis was executed using IBM SPSS and MS Excel. Due to the minor size of the sample $(n=160)$, complex statistics were not executed. Therefore, this article exhibits only some conclusions from the whole investigation.

The survey entitled "Perception of creativity, artistry, entrepreneurship, leadership and managerial abilities" lasted 34 days, i.e., from $20^{\text {th }}$ December 2020 to $23^{\text {rd }}$ January 2021. Two 
undistinguishable surveys, one in English and the other in Polish, were distributed by direct contact (sending requests to participate in the survey) and using indirect public utensils (social networks, collective messages to various types of communities). The number of people asked to participate in the investigation is estimated at approximately 2-3 thousand. Eight hundred seventy-nine people were interested in taking part in the survey, which was judged by clicking on the link leading to the survey. The authentic contribution to the study, consisting of filling in the questionnaire, was attended by 160 individuals, which is $18.2 \%$ of those interested in taking part in the research. The average time spent filling in the questionnaire was almost 33 minutes, and the typical respondent was 38 years old. Among the respondents: women represented $42.5 \%$ and men $57.5 \%$; people with higher education (bachelor, master, engineer) $64.57 \%$, people with doctoral, postdoctoral, or professor degrees $18.90 \%$, people with secondary education $15.75 \%$. The respondents originated from 28 countries: $74 \%$ from developed countries and $26 \%$ from developing countries (United Nations, 2021). 71.7\% were from European countries, 28.3\% from non-European countries; $49.6 \%$ from Poland, and $50.4 \%$ from other countries.

\section{Current state of knowledge}

Communism as the almighty demon, and ethnocentric individualism as an internal way of individual's determinism, are two dominant metatheories explaining post-communist societies' social capital weakness. Dilemmas, exceeding generations and material differences, occupy the minds of both national decision-makers and creative individuals on whom the quality of the social fabric depends. Weak but socially approved social capital practices combine corruption, bribery, and favoritism and achieving institutional fairness. Decades of convergence with mature democracies help people have different aspirations, well suited to the context of 
post-communist transformation, to make up for the delay of decades gripping the jaws of communism (Soaita \& Wind, 2020). Change between publicly- and private-owned resources influences people's minds, behaviors, and goals (Huber \& Montag, 2020). Researchers investigated the quality of social capital among many post-communist societies (Dolšak, 2019; Markowska-Przybyła, 2020; Nicoara, 2018; Soaita \& Wind, 2020).

Creator's identity may be explicated in the context of personalities dealing with profit- or non-profit organization's creator (Fauchart \& Gruber, 2011), classical arts - literature creator (Ottery, 2006), music creator (Tillay \& Chapman, 2019), new arts - anime creator (Reysen et al., 2020), social media content creator (Maynard, 2021), religious institution creator (Jones \& Massa, 2013), fake-news or rumor creator (Dong et al., 2019). Academics accentuate the shifting contexts and need for regulation to these deviations.

An artist's identity has been described historically as an artisan, a genius, a doer, a God's will doer, a master, a holy man in touch with the hidden, a cultural aristocrat, a knowledge worker, a professional, an entrepreneur, a freedom maker, an influencer, a value or idea guardian, a collaborator, a superman (Deresiewicz, 2020; Tatarkiewicz, 2015). In addition, the artist's identity may be identified as a copyist, a conceptualist, an artistic craftsman (artisan), and a creator (Szostak \& Sułkowski, 2020a).

The manager may be perceived as an administrator (an official), a manager-theoretician, a professional, a creative manager (a leader). A manager with extraordinary creativity and competence in his field can be named a management artist; it will also be authorized to call the manager as an artist/virtuoso who, achieving his ideas, knows how to organize reality according to his intentions (Szostak \& Sułkowski, 2020a). Researches of educational institutions reveal factors affecting managerial creativity (alphabetically): action-oriented, confidence, domain expertise, emotional stability, innovative leadership attributes, openness, professional development, risk tolerance (Alsuwaidi \& Omar, 2020). The 
literature emphasizes the intense influence of managers on their employees' creativity (Williams, 2001), but the level of creativity among managers varies depending on many factors, e.g., gender (Ahmad \& Zadeh, 2016). Creativity also has its paradoxes in the form of assumptions and unanswered questions (DeFillippi, Grabher, \& Jones, 2007).

The literature shows that the level of a leader's self-identity impacts vision communication with collaborators and subordinates positively (Venus et al., 2019). The narcissistic personality has an essential impact on a leader's identity integration (Chen, 2018), but it may negatively impact the organization (Szostak \& Sułkowski, 2020b). Transformational leadership and procedural justice positively and meaningfully affect manager trust, and manager trust positively impacts creating a maintainable organizational identity (Erat, Kitapçi, \& Akçin, 2020).

\section{Results and Discussion}

Discussing each research hypothesis separately, from the statistical point of view, we can say that: $\mathrm{H} 1$ (Polish citizens perceive the creative identities of a creator, artist, manager, entrepreneur, and leader differently than citizens of the rest of the world) is verified negatively. The chi-square value amounted to 390.35 for a creator, 394.21 for an artist, 406.27 for a manager, 40747 for an entrepreneur, and 411.35 for a leader. For the $d f=49$, using the chi-square distribution table, the chi-square value $=85.3506$ was found . Based on the above, the results are statistically significant for the significance level of $p=0.001$. H2 (The differences in perception of creative identities of a creator, artist, manager, entrepreneur, and leader by Polish and non-Polish citizens are not the same and vary in the case of each of the above identities) is verified negatively. The chi-square value $=40,193$. For the $d f=4$, using the chi-square distribution table, the chi-square value $=18.4668$. It means that the result is statistically significant for the significance level of $p=$ 
0.001. In each investigated creative identity case, the means of the 50 features perceived by Polish citizens are lower less than $2.10 \%$ comparing to non-polish citizens. It can be said that Polish citizens perceive creative identities slightly weaker than the rest of the world: see figure 1 .

Figure 1. Differences in perception of investigated creative identities: Polish versus non-Polish citizens

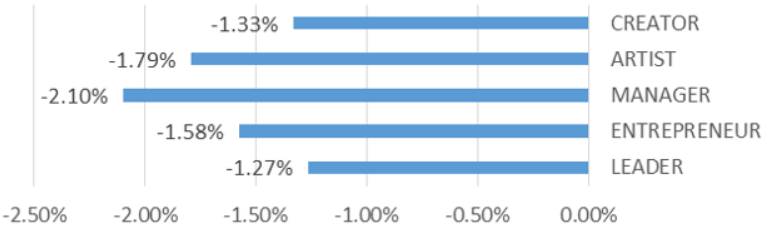

Source: own elaboration.

The negative verification of research hypotheses was astonishing and should be perceived as a novelty in the investigated area. Although both hypotheses were statistically verified negatively, the qualitative analysis of the in-depth characteristics of the investigated identities reveals that these identities interpenetrate and are considered to be more or less complementary.

\section{Creator's identity}

The ten most important features of a creator's identity perceived by Polish citizens are (in descending order): passion in action, selfconfidence, resistance to fails and failures, visualization skills (imagination), observation, courage, innovation, out of the box thinking (breaking patterns), originality, ability to synthesize and draw conclusions. On the other hand, the ten most critical features of a creator's identity perceived by non-Polish citizens are (in descending order): patience and persistence in achieving goals, passion in action, visualization skills (imagination), courage, self-confidence, 
originality, ability to set goals, ability to focus on details, innovation, honesty.

Figure 2. Perception of the most differently assessed features of a creator's identity

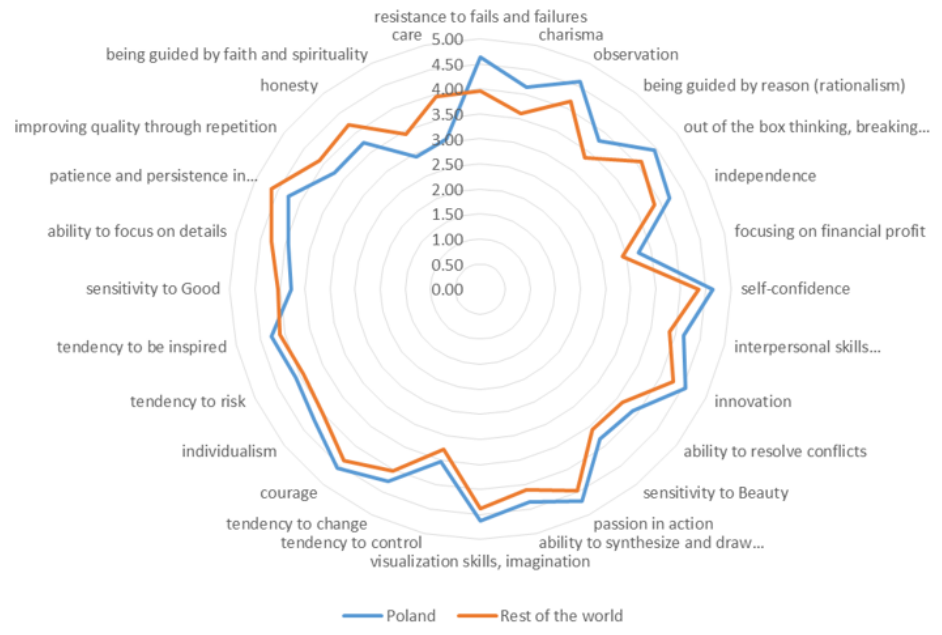

Source: own elaboration.

Perception of the particular 50 examined characteristics of the creator's identity by Polish citizens compared to non-Polish citizens reveals the following conclusions. The ten features of the creator's identity perceived as the least critical by Polish than non-Polish citizens are (in descending order): resistance to fails and failures, charisma, observation, being guided by reason (rationalism), out of the box thinking (breaking patterns), independence, focusing on financial profit, self-confidence, interpersonal skills (communicativeness, reading emotions, sensitivity to others), innovation. The ten features of the creator's identity seen as the most critical by Polish than non-Polish citizens are (in ascending order): conservatism, disorder (mess, chaos, randomness in action), sensitivity to Truth, sensitivity to Good, ability to focus on details, patience and persistence in achieving goals, improving quality through repetition, honesty, being guided by faith and spirituality, care. The ten features of the creator's identity perceived the most similarly by 
Polish and non-Polish citizens are pragmatism (practicality), connecting contradictions, justice, setting goals, efficiency, ability to analyze, leadership, a tendency to plan, ambition, responsibility. The variety of disparities in the answers referring to the creator's identity seen by Polish and non-Polish citizens may be observed in figure 2 and figure 3.

Figure 3. Perception of a creator's identity: Poland versus the rest of the world

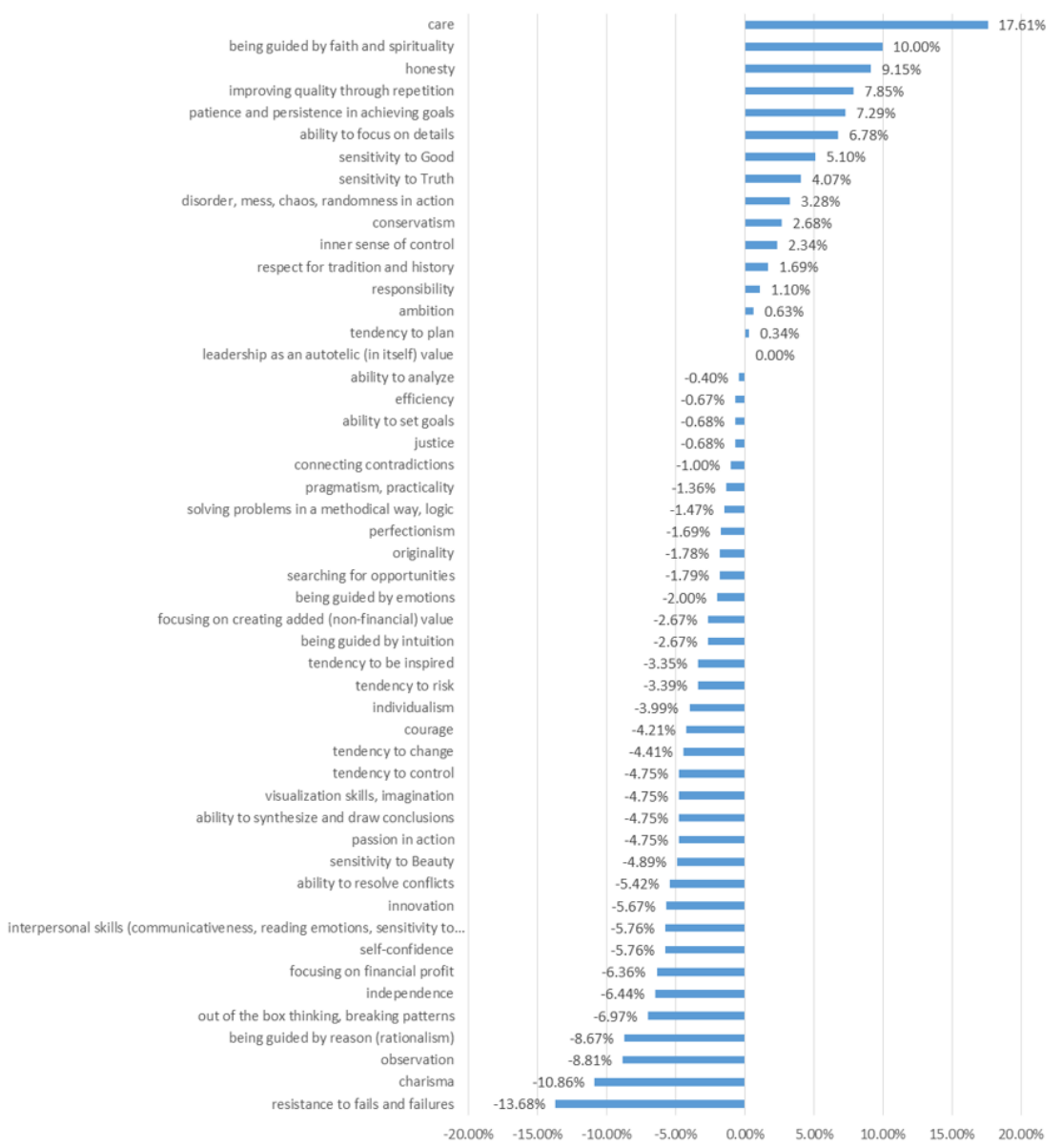

Source: own elaboration. 


\section{Artist's identity}

The ten most principal features of an artist's identity perceived by Polish citizens are (in descending order): passion in action, selfconfidence, visualization skills, imagination, originality, sensitivity to Beauty, observation, patience and persistence in achieving goals, individualism, tendency to be inspired, resistance to fails and failures. Conversely, the ten most vital features of an artist's identity seen by non-Polish citizens individuals are (in descending order): passion in action, patience and persistence in achieving goals, visualization skills (imagination), originality, improving quality through repetition, self-confidence, ability to focus on details, tendency to be inspired, courage, ambition.

Figure 4. Perception of the most differently assessed features of an artist's identity

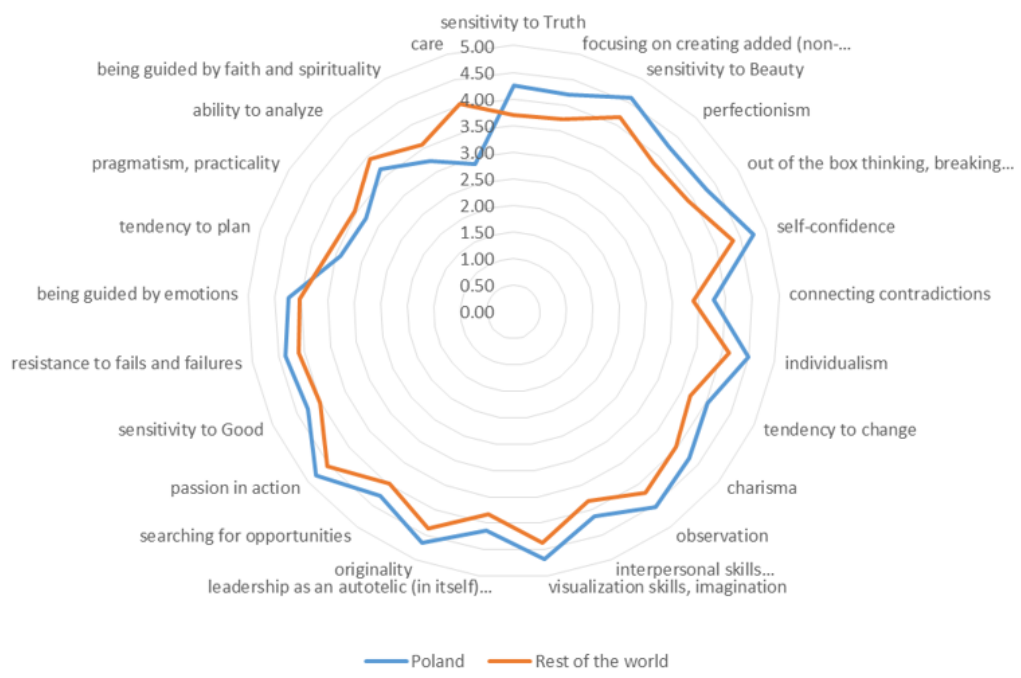

Source: own elaboration.

Perception of the particular 50 studied qualities of the artist's identity by Polish and non-Polish citizens reveals the following conclusions. The ten features of the artist's identity perceived as the 
least critical by Polish than non-Polish citizens are (in descending order): sensitivity to Truth, focusing on creating added (non-financial) value, sensitivity to Beauty, perfectionism, out of the box thinking (breaking patterns), self-confidence, connecting contradictions, individualism, tendency to change, charisma. The ten attributes of the artist's identity perceived as the most critical by Polish than non-Polish citizens are (in ascending order): a tendency to control, focusing on financial profit, respect for tradition and history, a tendency to risk, an inner sense of control, a tendency to plan, pragmatism (practicality), ability to analyze, being guided by faith and spirituality, care. The ten features of the artist's identity perceived the most similarly by Polish and non-Polish citizens are courage, ability to synthesize and draw conclusions, patience and persistence in achieving goals, efficiency, justice, conservatism, innovation, improving quality through repetition, ability to resolve conflicts, ability to focus on details. The whole spectrum of differences in the responses about the artist's identity perceived by Polish and non-Polish citizens shows figure 4 and figure 5 . 
Figure 5. Perception of an artist's identity: Poland versus the rest of the world

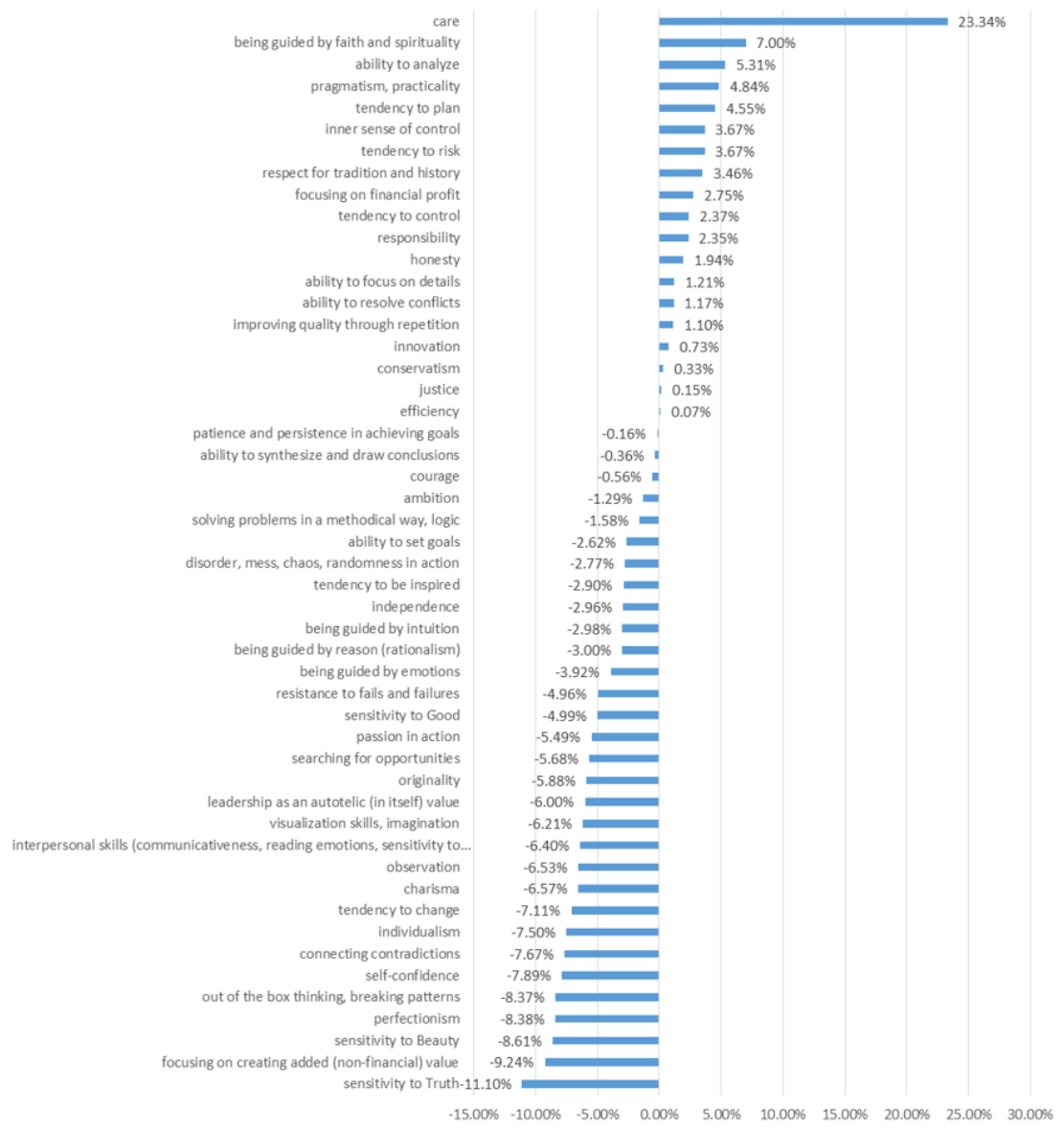

Source: own elaboration. 


\section{Manager's identity}

Figure 6. Perception of a manager's identity: Poland versus the rest of the world

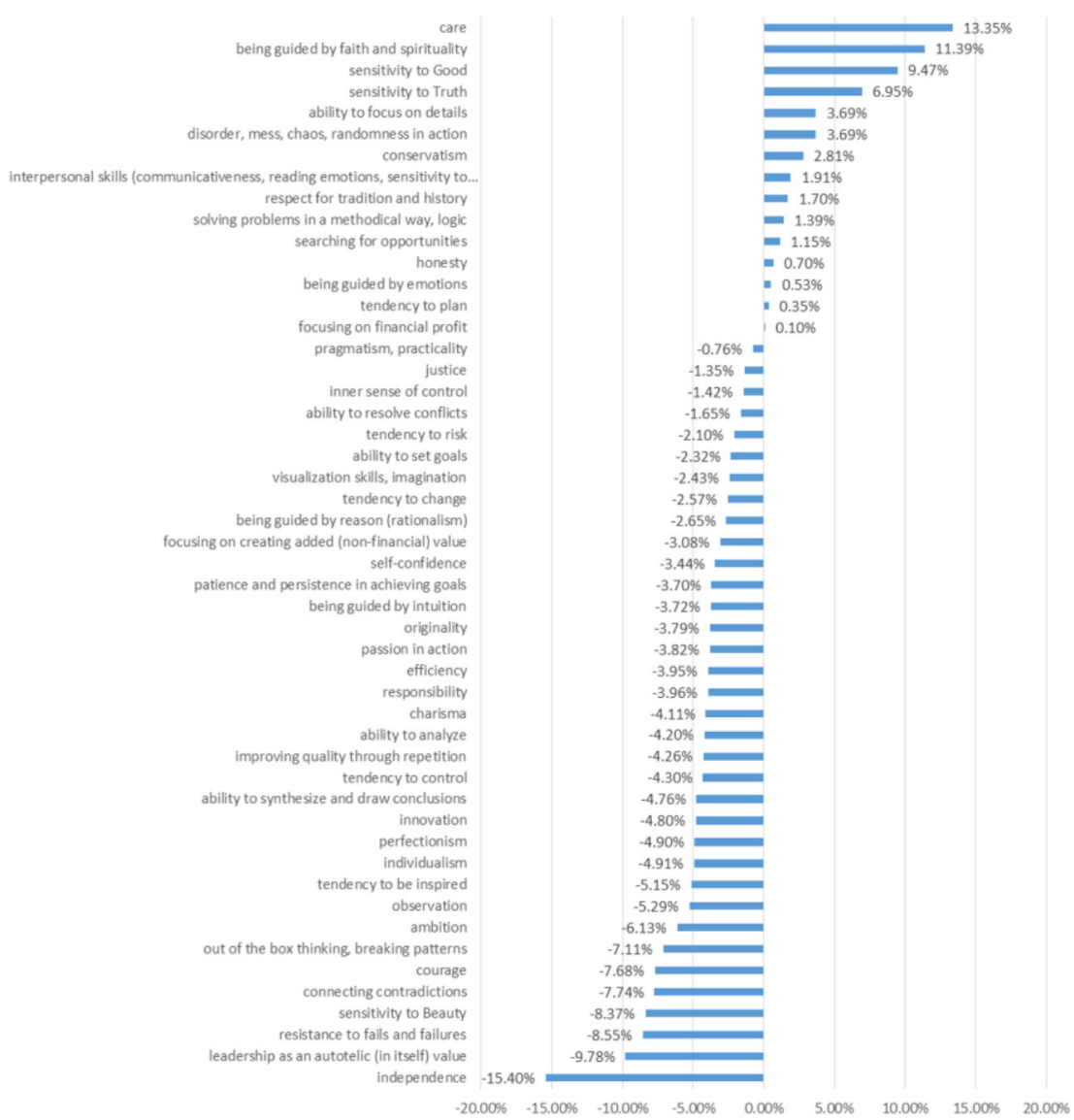

Source: own elaboration.

The ten most important features of a manager's identity perceived by Polish citizens are (in descending order): efficiency, responsibility, ability to analyze, patience and persistence in achieving goals, ability to set goals, ability to resolve conflicts, self-confidence, a tendency to plan, resistance to fails and failures, ambition. 
The ten most important features of a manager's identity perceived by non-Polish citizens are (in descending order): a tendency to plan, efficiency, ability to resolve conflicts, responsibility, ability to set goals, interpersonal skills (communicativeness, reading emotions, sensitivity to others), patience and persistence in achieving goals, ability to analyze, self-confidence, searching for opportunities.

Figure 7. Perception of the most differently assessed features of a manager's identity

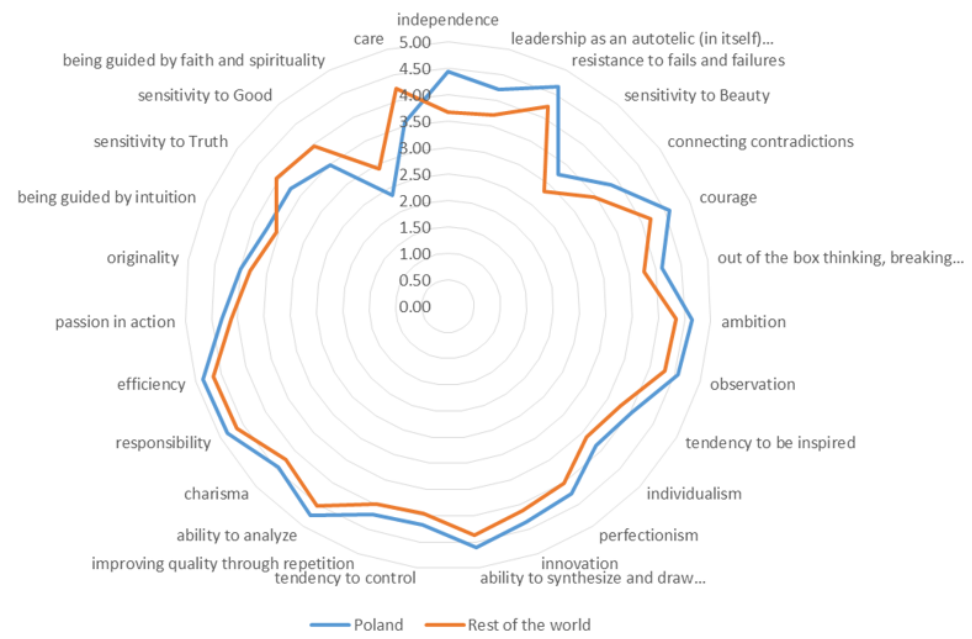

Source: own elaboration.

Perception of the particular 50 investigated features of the manager's identity by Polish citizens compared to non-Polish citizens reveals the following conclusions. The ten features of the manager's identity perceived as the least critical by Polish than non-Polish citizens are (in descending order): independence, leadership, resistance to fails and failures, sensitivity to Beauty, connecting contradictions, courage, out of the box thinking (breaking patterns), ambition, observation, tendency to be inspired. The ten features of the manager's identity perceived as the most critical by Polish than non-Polish citizens are (in ascending order): solving problems in a methodical way (logic), respect for tradition and his- 
tory, interpersonal skills (communicativeness, reading emotions, sensitivity to others), conservatism, disorder (mess, chaos, randomness in action), ability to focus on details, sensitivity to Truth, sensitivity to Good, being guided by faith and spirituality, care. The ten features of the manager's identity perceived the most similarly by Polish and non-Polish citizens are the ability to resolve conflicts, an inner sense of control, justice, pragmatism (practicality), focusing on financial profit, a tendency to plan, being guided by emotions, honesty, searching for opportunities, solving problems in a methodical way (logic). The range of differences in the manager's identity perceived by managers and nonmanagers shows figure 6 and figure 7. 


\section{Entrepreneur's identity}

Figure 8. Perception of an entrepreneur's identity: Poland versus the rest of the world
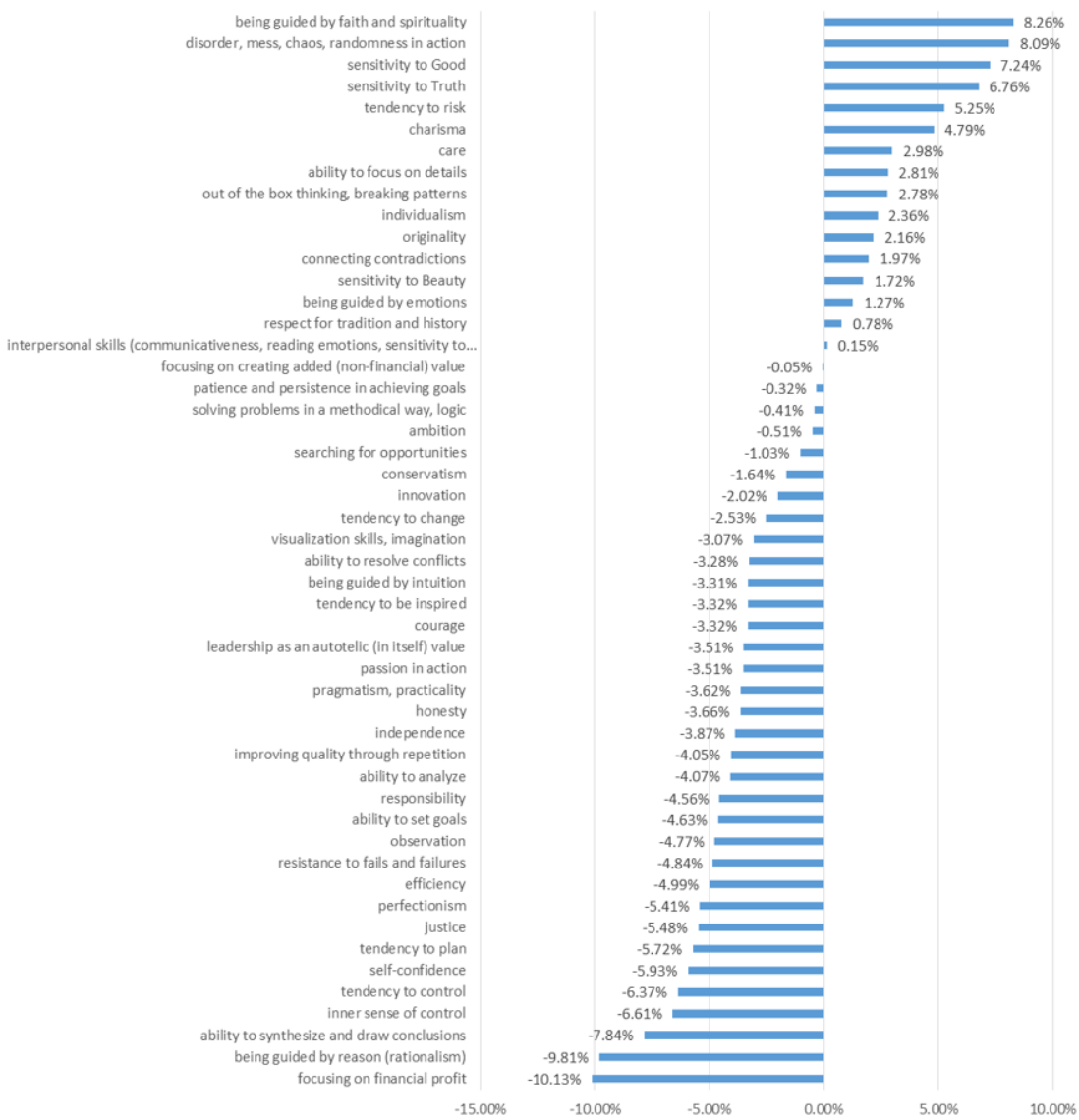

Source: own elaboration.

The ten most important features of an entrepreneur's identity perceived by Polish citizens are (in descending order): focusing on financial profit, self-confidence, ability to set goals, responsibility, efficiency, resistance to fails and failures, searching for opportunities, a tendency to plan, patience and persistence in achieving goals, courage. The ten most important features of an 
entrepreneur's identity perceived by non-Polish citizens individuals are (in descending order): patience and persistence in achieving goals, searching for opportunities, setting goals, responsibility, ambition, efficiency, courage, self-confidence, resistance to fails and failures, innovation.

Figure 9. Perception of the most differently assessed features of an entrepreneur's identity

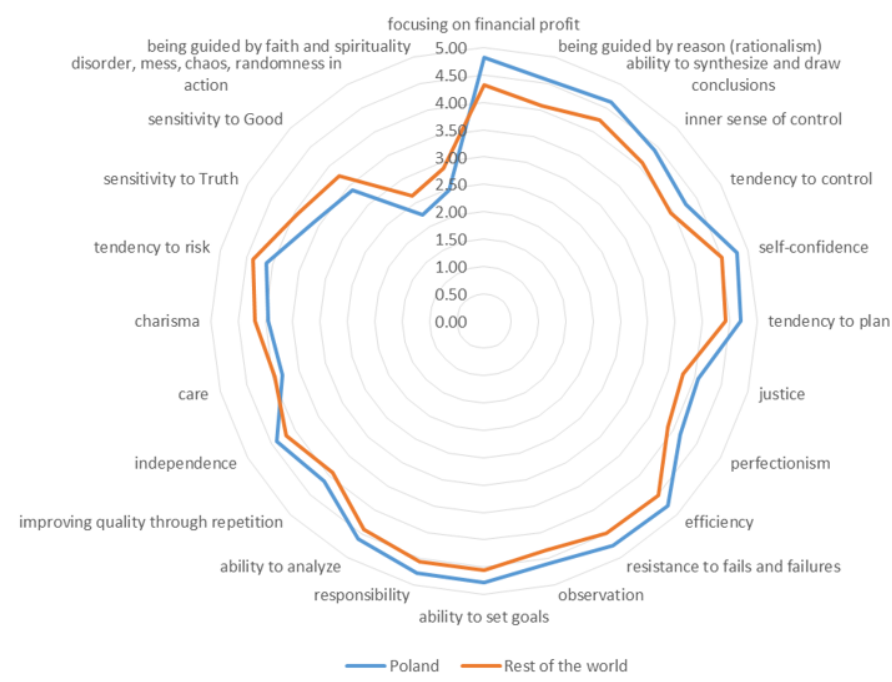

Source: own elaboration.

Perception of the particular 50 examined features of the entrepreneur's identity by Polish and non-Polish citizens reveal the following conclusions. The ten features of the entrepreneur's identity seen as the least critical by Polish than non-Polish citizens are (in descending order): focusing on financial profit, being guided by reason (rationalism), ability to synthesize and draw conclusions, an inner sense of control, tendency to control, self-confidence, a tendency to plan, justice, perfectionism, efficiency. The ten features of the entrepreneur's identity seen as the most critical by Polish than non-Polish citizens are (in ascending order): individualism, out of the box thinking, breaking patterns, ability to focus on details, care, charisma, a tendency to risk, sensitivity to Truth, 
sensitivity to Good, disorder (mess, chaos, randomness in action), being guided by faith and spirituality. The ten features of the entrepreneur's identity perceived the most similarly by Polish and nonPolish citizens are: conservatism, searching for opportunities, ambition, methodically solving problems (logic), patience and persistence in achieving goals, focusing on creating added (non-financial) value, interpersonal skills (communicativeness, reading emotions, sensitivity to others), respect for tradition and history, being guided by emotions, sensitivity to Beauty. The variety of disparities in the answers referring to the entrepreneur's identity seen by Polish and non-Polish citizens displays figure 8 and figure 9 .

\section{Leader's identity}

The ten most important features of a leader's identity perceived by Polish citizens are (in descending order): the ability to set goals, charisma, ability to resolve conflicts, resistance to fails and failures, self-confidence, courage, patience and persistence in achieving goals, responsibility, interpersonal skills (communicativeness, reading emotions, sensitivity to others), observation. The ten most important features of a leader's identity perceived by non-Polish citizens are (in descending order): charisma, responsibility, ability to resolve conflicts, patience and persistence in achieving goals, ability to set goals, self-confidence, interpersonal skills (communicativeness, reading emotions, sensitivity to others), courage, ambition, a tendency to plan. 
Figure 10. Perception of the most differently assessed features of a leader's identity

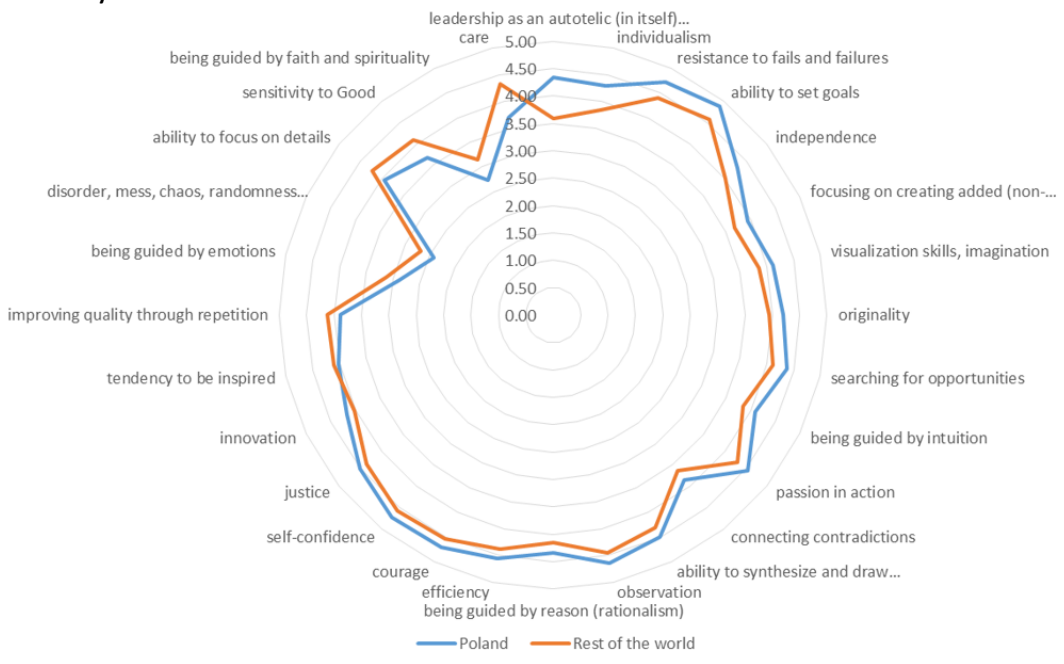

Source: own elaboration. 
Figure 11. Perception of a leader's identity: Poland versus the rest of the world

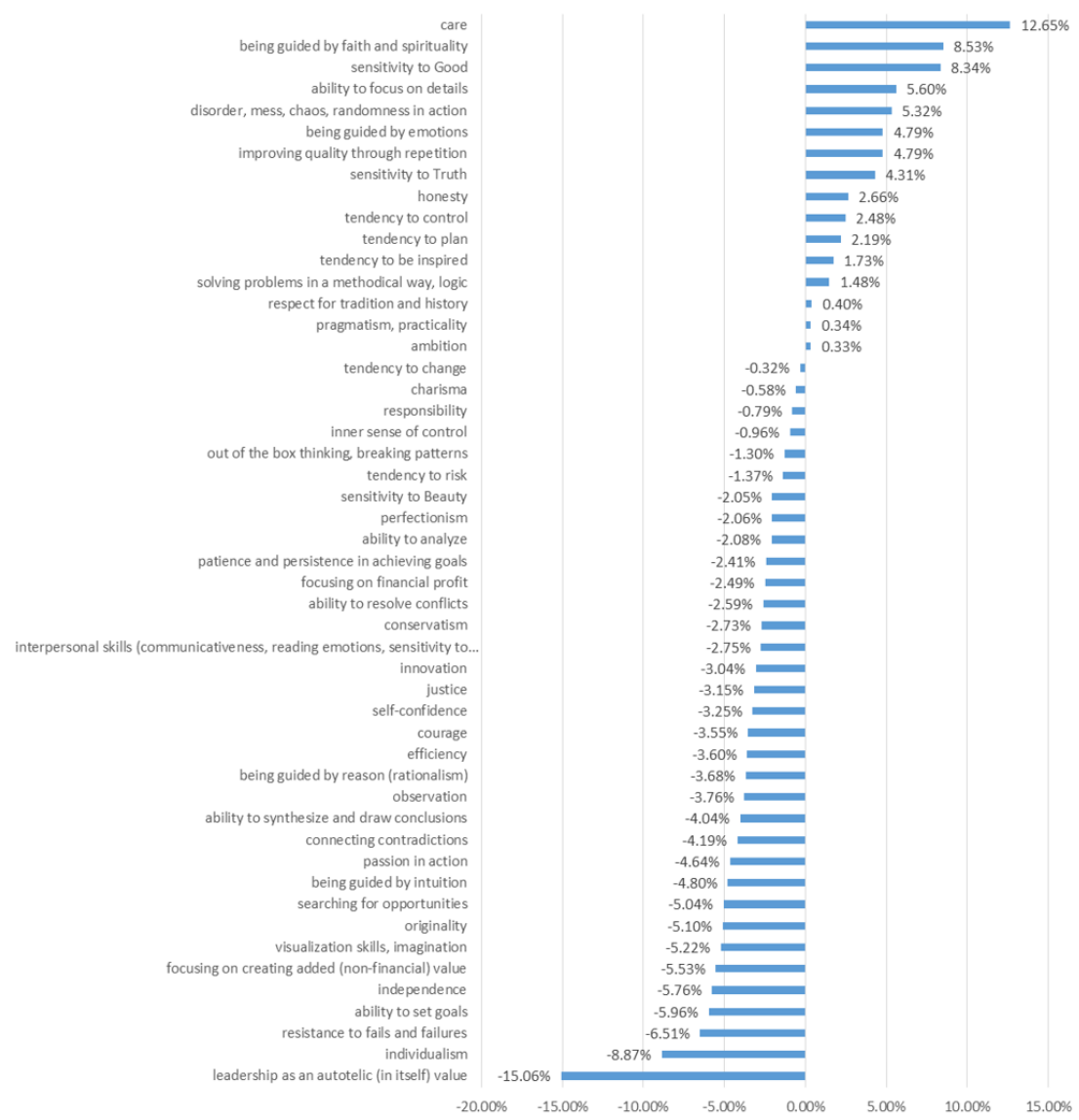

Source: own elaboration.

Perception of the specific 50 explored features of the leader's identity by Polish and non-Polish citizens reveals the following conclusions. The ten features of the leader's identity perceived as the least critical by Polish than non-Polish citizens are (in descending order): leadership as an autotelic (in itself) value, individualism, resistance to fails and failures, ability to set goals, independence, focusing on creating added (non-financial) value, visualization skills 
by intuition. The ten features of the leader's identity perceived as the most critical by Polish than non-Polish citizens are (in ascending order): a tendency to control, honesty, sensitivity to Truth, improving quality through repetition, being guided by emotions, disorder (mess, chaos, randomness in action), ability to focus on details, sensitivity to Good, being guided by faith and spirituality, care. The ten features of the leader's identity perceived the most similarly by Polish and non-Polish citizens are a tendency to risk, out of the box thinking (breaking patterns), an inner sense of control, responsibility, charisma, a tendency to change, ambition, pragmatism (practicality), respect for tradition and history, solving problems in a methodical way (logic). The whole range of differences in perception of the leader's identity by managers and nonmanagers displays figure 10 and figure 11 .

\section{Final remarks}

The limitations of the research are: 1) The research was run during the beginning of the COVID-19 pandemic; 2) The research sample $(n=160)$ was relatively small in comparison to the analyzed problem; 3) Conclusions cannot be widely representative due to complexity of the research problem.

The research results can be used by: 1) Leaders and managers for a) better understanding the layers of personality and complex identity in the context of Polish culture, b) comparison of own identity with the general perception of a particular role in reference do Polish society; 2) Researchers wanting to investigate the similarities and differences between identity and its perception in area of creative identities in reference do Polish perspective.

Potential questions for future qualitative research or the hypothesis for further quantitative investigations may be the following: 1) Self-perception may vary from the perception of the identity depending on the belonging to the particular society; 2) Self-perception is similar to the identity features perceived by society if their nation structure is similar. 


\section{References}

Adler, N. J. (2006). The arts \& leadership: Now that we can do anything, what will we do? Academy of Management Learning and Education, 5(4), 486-499. DOI: $10.5465 /$ AMLE.2006.23473209.

Ahmad, S. M., \& Zadeh, Z. F. (2016). Gender Differences on the Variables of Emotional Intelligence, Creative-Potential and Job Satisfaction in Managers. Pakistan Journal of Psychology, 47(2), 61-77. Retrieved from http://

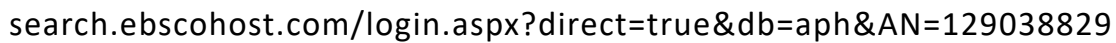
\&site=ehost-live. Access: 2021/04/06

Alsuwaidi, K. A. K. Y., \& Omar, A. J. (2020). Structural model of principals' innovative leadership attributes on managerial creativity. International Journal of Sustainable Construction Engineering and Technology, 11(2), 150-156. DOI: 10.30880/ijscet.2020.11.02.017.

Alvesson, M., \& Blom, M. (2015). Less Followership, Less Leadership? An Inquiry Into the Basic But Seemingly Forgotten Downsides of Leadership. M@n@gement, 18(3), 266-282.

Baker, S., Marshburn, D. M., Crickmore, K. D., Rose, S. B., Dutton, K., \& Hudson, P. C. (2012). What do you do? Perception of nurse manager responsibilities. Nursing Management, 43(12), 24-29. DOI: 10.1097/01. NUMA.0000422890.99334.21.

Bayrakci, B., Forouz, A., Şahin, A. B., Abali, M., \& Aliyeva, G. Z. (2009). Disease painting or painting disease: How does illness and hospitalisation affect children's artistry? Perception, 38(11), 1721-1727. DOI: 10.1068/p6138.

Bulei, I., Mihalcioiu, V., \& Tucmeanu, A. (2014). The Professional vs. the Manager - Identity Issues and Key Features. Valahian Journal of Economic Studies, 5(3), 31-36.

Bureau, S., \& Zander, I. (2014). Entrepreneurship as an art of subversion. Scandinavian Journal of Management, 30(1), 124-133. DOI: 10.1016/ j.scaman.2013.12.002.

Carroll, B., \& Levy, L. (2008). Defaulting to management: Leadership defined by what it is not. Organization, 15(1), 75-96. DOI: 10.1177/1350508407084486. 
Chen, L. (2018). Thinking paradoxically: How and when female narcissistic leaders integrate gender-leader identities. Social Behavior and Personality, 46(2), 339-352. DOI: 10.2224/sbp.6910.

Clarke, J. S., \& Holt, R. (2019). Images of entrepreneurship: Using drawing to explore entrepreneurial experience. Journal of Business Venturing Insights, 11(June), 2019-2021. DOI: 10.1016/j.jbvi.2019.e00129.

Damásio, M. J., \& Bicacro, J. (2017). Entrepreneurship education for film and media arts: How can we teach entrepreneurship to students in the creative disciplines? Industry and Higher Education, 31(4), 253-266. DOI: 10.1177/0950422217713110.

DeFillippi, R., Grabher, G., \& Jones, C. (2007). Introduction to paradoxes of creativity: managerial and organizational challenges in the cultural economy. Journal of Organizational Behavior, 28, 511-521. DOI: 10.1002/job.

Deresiewicz, W. (2020). The Death of the Artist: How Creators Are Struggling to Survive in the Age of Billionaires and Big Tech. New York: Henry Holt and Co.

Dolšak, N. (2019). Bowling Together: Mobilization of Collective Action by Environmental NGOs. Nonprofit Policy Forum, 8(1), 25-44. DOI: 10.1515/ npf-2016-0025.

Dong, X., Liu, Y., Wu, C., Lian, Y., \& Tang, D. (2019). A double-identity rumor spreading model. Physica A: Statistical Mechanics and Its Applications, 528. DOI: $10.1016 /$ j.physa.2019.121479.

Dufour, L., Maoret, M., \& Montani, F. (2020). Coupling High Self-Perceived Creativity and Successful Newcomer Adjustment in Organizations: The Role of Supervisor Trust and Support for Authentic Self-Expression. Journal of Management Studies, 57(8), 1531-1555. DOI: 10.1111/joms.12547.

Elstad, B., \& Jansson, D. (2020). From Artist to Manager-Working Conditions, Career Satisfaction, and Professional Identity among Graduated Arts Management Students. Journal of Arts Management Law and Society, 50(3), 184-198. DOI: 10.1080/10632921.2020.1746717.

Erat, S., Kitapçi, H., \& Akçin, K. (2020). Managerial perception and organizational identity: A comparative analysis. Sustainability, 12(6), 1-16. DOI: 10.3390/su12062278. 
Fauchart, E., \& Gruber, M. (2011). Darwinians, communitarians, and missionaries: The role of founder identity in entrepreneurship. Academy of Management Journal, 54(5), 935-957. DOI: 10.5465/amj.2009.0211.

Gangi, J. (2018). Classical guitar study as creativity training: Potential benefits for managers and entrepreneurs. Journal of Open Innovation: Technology, Market, and Complexity, 4(45), 1-10. DOI: 10.3390/joitmc4040045.

Hallier, J. (2004). Embellishing the past: Middle manager identity and informality in the implementaion of new technology. New Technology, Work and Employment, 19(1), 43-62. DOI: 10.1111/j.1468-005X.2004.00127.x.

Hatch, M. J., Kostera, M., \& Koźmiński, A. K. (2006). The three faces of leadership: Manager, artist, priest. Organizational Dynamics, 35(1), 49-68. DOI: 10.1016/j.orgdyn.2005.12.003.

Hracs, B. J. (2015). Cultural Intermediaries in the Digital Age: The Case of Independent Musicians and Managers in Toronto. Regional Studies, 49(3), 461-475. DOI: 10.1080/00343404.2012.750425.

Huber, P., \& Montag, J. (2020). Homeownership, Political Participation, and Social Capital in Post-Communist Countries and Western Europe. Kyklos, 73(1), 96-119. DOI: 10.1111/kykl.12218.

Jankurová, A., Ljudvigová, I., \& Gubová, K. (2017). Research of the nature of leadership activities. Economics and Sociology, 10(1), 135-151. DOI: 10.14254/2071-789X.2017/10-1/10.

Jones, C., \& Massa, F. G. (2013). From Novel Practice to Consecrated Exemplar: Unity Temple as a Case of Institutional Evangelizing. Organization Studies, 34(8), 1099-1136. DOI: 10.1177/0170840613492073.

Lähdesmäki, M. (2012). Construction of owner-manager identity in corporate social responsibility discourse. Business Ethics, 21(2), 168-182. DOI: 10.1111/ j.1467-8608.2011.01644.x.

Lehmann, J., \& Gaskins, B. (2019). Learning scientific creativity from the arts. Palgrave Communications, 5 (95), 1-5. DOI: 10.1057/s41599-019-0308-8.

Leso, G., Dias, G., Ferreira, J. P., Gama, J., \& Couceiro, M. S. (2017). Perception of Creativity and Game Intelligence in Soccer. Creativity Research Journal, 29(2), 182-187. DOI: 10.1080/10400419.2017.1302779. 
Lewis, K. V., Ho, M., Harris, C., \& Morrison, R. (2016). Becoming an entrepreneur: Opportunities and identity transitions. International Journal of Gender and Entrepreneurship, 8(2), 1-6. DOI: http://dx.doi.org/10.1108/ IJGE-02-2015-0006.

López-Fernández, M., Romero-Fernández, P. M., \& Aust, I. (2018). Socially responsible human resource management and employee perception: The influence of manager and line managers. Sustainability (Switzerland), 10(12), 1-19. DOI: 10.3390/su10124614.

Lord, R. G., \& Brown, D. J. (2001). Leadership, values, and subordinate self-concepts. The Leadership Quarterly, 12, 133-152.

Lutas, M., Nistor, R., Radu, M., \& Beleiu, I. (2020). Perceptions regarding the profile of an ideal project manager. Amfiteatru Economic, 22(54), 608-622. DOI: 10.24818/EA/2020/54/608.

Markowska-Przybyła, U. (2020). Does social capital matter for total factor productivity? Exploratory evidence from Poland. Sustainability (Switzerland), 12(23), 1-25. DOI: 10.3390/su12239978.

Maynard, A. D. (2021). How to Succeed as an Academic on YouTube. Frontiers in Communication, 5. DOI: 10.3389/fcomm.2020.572181.

McHugh, K. E. (2015). Touch at a distance: toward a phenomenology of film. GeoJournal, 80(6), 839-851. DOI: 10.1007/s10708-015-9650-6.

Nicoara, O. (2018). Cultural Leadership and Entrepreneurship As Antecedents of Estonia's Singing Revolution and Post-Communist Success. Baltic Journal of European Studies, 8(2), 65-91. DOI: 10.1515/bjes-2018-0016.

Nikolski, K. (2015). Leadership and Management: Practice of the Art of Influence. Annals of the "Constantin Brâncuşi” University of Târgu Jiu, Economy Series, 2(1), 31-39.

Nowak, S. (2007). Metodologia Badań Społecznych. Warsaw: Wydawnictwo Naukowe PWN.

Ottery, J. R. (2006). Who are they and what do they have to do with what i want to be? "the writing of multicultural identity and college success stories for firstyear writers." In Identity Papers: Literacy and Power in Higher Education (pp. 122-137). Logan: Utah State University Press. 
Postuła, A., \& Majczyk, J. (2018). Managers and leaders in need of entrepreneurial competences. Entrepreneurial Business and Economics Review, 6(1), 91-103. DOI: 10.15678/EBER.2018.060105.

Raso, R., Fitzpatrick, J. J., \& Masick, K. (2020). Clinical nurses' perceptions of authentic nurse leadership and healthy work environment. Journal of Nursing Administration, 50(9), 489-494. DOI: 10.1097/NNA.0000000000000921.

Reysen, S., Katzarska-Miller, I., Plante, C. N., Roberts, S. E., Gerbasi, K. C., Brooks, T. R., \& Tague, A. M. (2020). Anime and global citizenship identification. The Phoenix Papers, 4(2), 48-61. DOI: 10.17605/OSF.IO/JXPTQ.

Soaita, A. M., \& Wind, B. (2020). Urban Narratives on the Changing Nature of Social Capital in Post-Communist Romania. Europe-Asia Studies, 72(4), 712-738. DOI: 10.1080/09668136.2020.1718064.

Stuke, K. B. (2013). Understanding Leadership Through Leadership Understandings. Journal of Leadership Studies, 7(2), 55-61. DOI: 10.1002/ jls.21291.

Szostak, M. (2020). Creativity and Artistry in Organ Music. The Organ, 391, 24-31. Retrieved from https://depot.ceon.pl/handle/123456789/19170. Access: 11.03.2021.

Szostak, M., \& Sułkowski, Ł. (2020a). Manager as an artist: Creative endeavour in crossing the borders of art and organizational discourse. Creativity Studies, 13(2), 351-368. DOI: 10.3846/cs.2020.11373.

Szostak, M., \& Sułkowski, Ł. (2020b). Kitsch in Management: characteristic forms, carriers and propagators. In Education Excellence and Innovation Management: A 2025 Vision to Sustain Economic Development during Global Challenges: Proceedings of the 35th International Business Information Management Association Conference (IBIMA) (pp. 7584-7598), 1-2 April 2020. Retrieved form https://www.researchgate.net/publication/345996764_Kitsch _in_Management_characteristic_forms_carriers_and_propagators. Access: 14.03.2021.

Szostak, M., \& Sułkowski, Ł. (2021a). Identity crisis of artists during the COVID-19 pandemic and shift towards entrepreneurship. Entrepreneurial Business and Economics Review, 9(3), 87-102. DOI: 10.15678/ EBER.2021.090306. 
Szostak, M., \& Sułkowski, Ł. (2021b). The Identity and Self-Perception of Artists-Managers. Problems and Perspectives in Management, 19(1), 372-386. DOI: 10.21511/ppm.19(1).2021.32.

Taleghani, M. (2012). Impact of Attitudes on Managers Creativity. Procedia Social and Behavioral Sciences, 40, 65-70. DOI: 10.1016/j.sbspro.2012.03.162.

Tatarkiewicz, W. (2015). Historia estetyki. Warsaw: Wydawnictwo Naukowe PWN.

Tillay, R., \& Chapman, C. C. (2019). A new digital method for assessing the diversity of creator identities in the howard-tilton memorial library media services DVD collection. Music Reference Services Quarterly, 22(1-2), 57-64. DOI: 10.1080/10588167.2019.1601421.

Toscher, B. (2019). Entrepreneurial Learning in Arts Entrepreneurship Education: A Conceptual Framework. Arti, 8(1), 3-22.

Toscher, B. (2020). Blank Canvas: Explorative Behavior and Personal Agency in Arts Entrepreneurship Education. Artivate: A Journal of Entrepreneurship in the Arts, 9(2), 19-44. DOI: 10.34053/artivate.9.2.115.

United Nations (2021). Country classification. World Economic Situation and Prospects 2020. Retrieved from https://www.un.org/development/ desa/dpad/wp-content/uploads/sites/45/WESP2020_FullReport.pdf. Access: 02.04.2021.

Venus, M., Johnson, R. E., Zhang, S., Wang, X. H. (Frank), \& Lanaj, K. (2019). Seeing the Big Picture: A Within-Person Examination of Leader Construal Level and Vision Communication. Journal of Management, 45(7), 2666-2684. DOI: 10.1177/0149206318761576.

Walter, H. M. (2015). Artist, Professional, Gentleman: Designing the Body of the Actor-Manager, 1870-1900. London: Royal College of Art.

Williams, S. (2001). Increasing employees' creativity by training their managers. Industrial and Commercial Training, 33(2), 63-68. DOI: 10.1108/00197850110385642.

Wilson, C., \& Brown, M. (2012). Sound, space, image and music: Hybridity in creative process through technology, interactivity and collaboration. Journal of Music, Technology and Education, 5(1), 89-107. DOI: 10.1386/jmte.5.1.89_1. 
Wolf, C. (2019). Not lost in translation: Managerial career narratives and the construction of protean identities. Human Relations, 72(3), 505-533. DOI: 10.1177/0018726718778094.

Woodward, J. B., \& Funk, C. (2010). Developing the artist-leader. Leadership, 6(3), 295-309. DOI: 10.1177/1742715010368768.

Zhou, J., Shin, S. J., \& Cannella, A. A. (2008). Employee self-perceived creativity after mergers and acquisitions: Interactive effects of threat-opportunity perception, access to resources, and support for creativity. Journal of Applied Behavioral Science, 44(4), 397-421. DOI: 10.1177/0021886308328010. 